\title{
1. Introduction to the Handbook of Social Tourism
}

\author{
Anya Diekmann and Scott McCabe
}

Social tourism, the obverse of commercial tourism due to its explicit social motivation, is gaining momentum not only through the attention of policy makers, but also in research and amongst the academy. New books, special issues in prestigious journals, conference tracks and $\mathrm{PhD}$ theses in recent years are all testament to this renewed interest in tourism activity that is directed towards the achievement of positive social and personal outcomes for people who would not be able to access leisure or holiday travel without such social interventions.

Indeed, there has never been a more appropriate moment to restate the case for the social imperative of tourism as an industry and practice. We have consistently argued in our work on social tourism that the growth in recent interest is not an indication that social tourism is somehow an emerging area of activity, but that it has run in parallel to the development of the modern, industrial scale mass activity that characterizes tourism today (Minnaert et al. 2012). This has also been pointed out by other leading scholars working in related areas of equitableness and fair, responsible and sustainable tourism (e.g. Butcher 2003; Hall \& Brown 2006; Higgins-Desbiolles 2006). The structured development of social tourism in the early twentieth century was in the first place the result of social imbalances and a lack of access to holidays for some strata of society. The motivation for social organizations becoming involved in tourism provision of this kind was always based on a recognition of the positive contribution made to health and well-being (Walton 2013; Smith \& Diekmann 2017). With increasing democratization of tourism and the development of 'mass' tourism in the second half of the twentieth century, providing access to holidays became less of a priority for governments and social tourism funding schemes have been declining, in most European countries at least.

However, in the new millennium, there are a range of external challenges facing society in general, and the global tourism industry in particular. These challenges appear to hold the potential to undermine the very foundations upon which the system is based, threatening the long-term sustainability of tourism as an activity, notwithstanding the current crisis facing the global tourism system as a consequence of the Covid-19 pandemic. Three major issues related to tourism have dominated the global political and media debates in the last few years, namely: (1) social inequality, (2) climate change and (3) irresponsible consumption.

In that context, social tourism core values are resurgent, and the provision of and activity related to social tourism (re)gain a new urgency. While social tourism cannot 
resolve all issues, it can contribute at various levels to some of the above with social inequalities as one of the key issues.

\section{SOCIAL INEQUALITY}

Consensus is emerging that there is increasing wealth and income inequality, even in richer nations (McCall \& Percheski 2010; Heidenreich 2016; Ballas et al. 2017), meaning that access to tourism is becoming more concentrated among those who are wealthier in societies. Of course, the global patterns are not straightforward. As developing countries become wealthier, access to leisure and tourism specifically become more widespread and normalized amongst larger groups in society. As countries develop, opportunities to participate in tourism are more widely available to greater numbers and across different social groups. Whereas in developed countries, more diverse social demographic changes can result in a concentration of demand for tourism amongst a narrower section of society, sometimes meaning that growth in tourism overall is being driven by a smaller section of the middle classes and increasingly exclusive (Scheyvens \& Biddulph 2018). The UK is a good example. It is the fifth most unequal country in Europe (Eurostat 2019) and wealth inequality continues to rise, in spite of steps taken to address the issues through economic policy (Partington 2018). More than a fifth of the population lives on incomes that are below the poverty line once the costs of housing are taken into account. Inequality is a function of income, gender, ethnicity, age and geography. Therefore, inequality is more complex an issue and goes far beyond poverty measures, social class and unemployment.

Indeed, in relation to social tourism, it is perhaps more important to look beyond issues of poverty alone. For example, a recent study highlights that between 2015 and 2025, the numbers of people in England and Wales aged 65 plus will increase by 19.4 per cent and the numbers within that age group living with a disability will increase by 25 per cent (Guzman-Castillo et al. 2017). Schnitzler (2019) reports similar concerns in France. Of course, the fact that we are living in an ageing society is nothing new, and this is a global trend particularly amongst the most developed countries. And yet, what these studies show is the link between ageing and disability. An ageing society brings with it an increase in the burden of disability: in fact a quarter of the extra years gained after reaching age 65 will involve disability. It should be underlined, however, that increases in the proportion of people living with disability is a reflection of population ageing rather than an increase in the prevalence of disability. The point is that these figures have profound social and health care implications that need to be addressed.

The link between disabilities and impairments and access to full participation in citizenship rights, including leisure time and tourism and travel, is clearly an issue as can be seen in various recent studies with an interdisciplinary focus (e.g. Yu et al. 2018). In a recent study undertaken for Visit England for example, the proportion of the population with an impairment taking a domestic holiday in 2017 was 48 per cent, 
compared with a figure of 61 per cent of the total population (Visit England 2018). In fact, those people living with an impairment tend to be older and from a lower social grade. Visit England's research highlighted that whilst affordability was the main issue affecting people with a disability from being able to access a simple domestic break, other accessibility issues were also a factor. Not only does this represent a missed opportunity for the tourism industry in that there are clearly some people for whom tourism is desired but not available, but it also reveals that social interventions of the type provided by social tourism programmes could be highly effective in reducing inequalities and lead to possible benefits for older people living with disabilities (Shaw et al. 2005). However, not all countries face the same difficulties depending on the type of social tourism system and the providers involved in their delivery. In countries such as France and Belgium or Spain and Portugal, where either health insurance funds act as social tourism providers, or governmental policies fund specific programmes, particular offers exist to allow these precarious groups to participate in tourism and thus reduce inequalities in participation rates.

The need to fight exclusion has deep implications concerning public funding for health and social care. Research has shown that socially excluded groups derive important benefits from participation in tourism, and that social tourism can lead to a range of positive outcomes for social tourists, social and welfare policy, and society (McCabe 2019). Low-income families benefit from the opportunity to relax and recuperate from stressful or difficult personal circumstances, repair and build relationships, experience new activities and places as well as providing fun and happy memories for children (McCabe 2009). Related studies have found that for older people, there are benefits from improved social opportunities, reducing isolation and loneliness (Morgan et al. 2015; Mélon et al. 2018). Children and young people benefit from new experiences and learning (Minnaert 2012) and people with disabilities benefit from improved health (Shaw et al. 2005) and access to opportunities (Buhalis \& Darcy 2010). Across a range of diverse circumstances, types of people or social groups, social tourism has been shown not only to provide positive outcomes for the direct beneficiaries of social tourism programmes, but also holds potential for wider public policy outcomes (Diekmann et al. 2018). Eusébio et al. (2013) for example, analysed the economic impacts of health tourism programmes and discovered that they lead to direct cost savings for the public authorities in Portugal. Making tourism available for all people in society can help reduce inequality of access to participation, lead to cost savings in public spending, and help to create a more inclusive society (European Economic and Social Committee 2006).

\section{CLIMATE CHANGE}

It is without doubt that human-induced climate change is a fact and threatens to place immense pressures on economies and social institutions and norms, as well as on the natural environment (Becken 2019). Tourism's role in contributing to carbon dioxide emissions, the major driver of atmospheric heating, equates to about 8 per 
cent of total global emissions (Lenzen et al. 2018). About half of these emissions are attributable to the transport sector. There is a broad consensus that absolute and rapid reductions in greenhouse gases are required if there is to be any hope of limiting global warming to within $1.5^{\circ} \mathrm{C}$ of 1990 levels. To do so will require deep and wide-ranging changes in energy use and production, infrastructure, including transport, and industrial systems.

It is highly likely that such changes in production and consumption of tourism will involve a decrease in international travel and thus, if tourism is to continue to be promoted, an increase in domestic tourism. Becken (2019) cites World Travel and Tourism Council (WTTC) figures showing that 73 per cent of all tourism expenditure globally is derived from domestic tourism. As long as the travel component is not undertaken by air and there are strong energy policies in place to support the tourism and hospitality sector in well-planned and designed destinations, there is no reason why domestic tourism should not grow further and contribute to a more sustainable tourism system in the future, which is even more likely as a result of potential ongoing travel restrictions designed to halt the spread of the Coronavirus pandemic.

Social tourism, due to the public funding schemes at either national or regional level, is mainly organized in beneficiaries' own countries and therefore contributes to domestic tourism. In addition, we know that tourism can contribute significantly to tourists' sense of subjective well-being, particularly in the case of social tourists (McCabe \& Johnson 2013). Regarding impacts on policy, social tourism can contribute to greater sustainability for destinations through longer tourism seasons, evening out the spread of demand, providing more stable employment and increased tax revenues (Cisneros-Martínez et al. 2018). Eusébio et al. (2016) examined the economic contribution of senior tourism programmes provided by the INATEL Foundation to the economic development of tourism destinations. This study found that the economic contributions to destinations outweighed the costs of the programme based on an input-output model of the Portuguese economy and the authors concluded that social tourism could be used to help diversify and restructure the destination economy, in addition to creating jobs, generating income and contributing to the development of the destination. The economic sustainability of destinations is of critical importance given that many European destinations are in peripheral regions, which are dependent on tourism, and a decline in visitor demand could lead to declining living standards, increased unemployment, and lack of investment in infrastructure, leading to a gradual restructuring towards a low-wage economy and social exclusion (McCabe 2018). Relatedly, one of the most important issues associated with social tourism is the sometimes lack of perceived congruence between the image a destination wishes to portray to its main markets, and the image that might be associated with social tourism (such as poverty and social exclusion) (Diekmann et al. 2012). Perhaps one way in which destinations could overcome issues of image incongruity is to focus on the social sustainability aspects of social tourism, relating to the Sustainable Development Goals agenda (McCabe 2018). 


\section{IRRESPONSIBLE CONSUMPTION}

With a 5 per cent growth of tourism in 2018 the number of international tourist arrivals reached the 1.4 billion mark (UNWTO 2019). The vast number of tourism activities all over the world mean faster consumption and a greater range of and more diverse supply channels, often through innovative schemes and from so-called 'sharing economy' provision. The latter often leaves employees in the tourism industry with less secure and/or greater temporary/seasonal jobs within the new, 'gig' economies, and often without access to social security provision. The threat of mass unemployment in the tourism and hospitality sector brought about by widespread Covid-19 lockdown's affecting the tourism and hospitality industries has highlighted the precariousness of these jobs. Social tourism policy makers and providers tackle these problems as they advocate a responsible approach to employment (Cisneros-Martínez et al. 2018) with permanent and decent working contracts and conditions (Minnaert et al. 2009; Diekmann \& McCabe 2011) and to destination management, whereby demand is more evenly distributed throughout the season. Unfortunately, to date not many researchers have looked into the employment aspects of social tourism, but there is an urgent need to tackle these issues as working conditions are deteriorating in the tourism sector (Baum 2015).

Indeed, further research is required to provide evidence regarding all the different issues discussed above. For instance, there is an urgent need for studies analysing the effects of exclusion from holiday-making on people, since there is very little research that has studied the long-term consequences on people who are not able to participate. Similarly, new forms of disadvantage are emerging, and so it is important to understand what are the sources of inequality as well as the new groups of affected people, so that we can understand how needs and demands will develop over time, and therefore, create new products and services to meet them. There is a need not only to better understand the positive health effects of tourism (relaxation, pleasure, learning, physical activity, relationships) but also the potential negative effects (relationship breakdown, over-indulgence, stress) (McCabe 2019). This will require a greater effort to engage in multi- and interdisciplinary research teams and projects, at a multinational scale, to ensure that social tourism programmes lead to optimal outcomes for those most in need of support in the future, and to meet the emerging needs of people in the developing world, to ensure that policies and programmes for social tourism are relevant to their needs.

Given these issues, and coupled with the fact that socio-economic systems will develop to lessen the reliance on human labour, leaving greater time and capacity for 'productive' leisure, i.e. that which contributes to creativity, personal fulfilment, health and well-being, education and so on, tourism destinations will need to adapt to new market conditions, including social tourism. To remain competitive in the long term, tourism destinations will require plans and policies that will distribute demand more evenly in space and time to avoid overcrowding and seasonality effects, as well as to provide opportunities for diverse market segments. Destinations will need to become more differentiated and adopt sophisticated targeting strategies, which must 
include a 'social segment' to ensure economic sustainability and efficient use of tourism resources. While social tourism cannot solve all the problems, it certainly can contribute to more sustainable tourism practices and restore essential human social values back into the mainstream tourism system.

\section{THE HANDBOOK}

This handbook therefore seeks to contribute to raising general awareness of the possibilities opened up by social tourism and how social tourism impacts on people. Although the last decade has seen an important increase in social tourism research, only a limited number of special issues or edited books dedicated to social tourism have emerged to date. A greater appreciation of the variety and diversity of social tourism initiatives can only be helpful in facilitating sharing of best practices, new opportunities for building networks of researchers and practitioners, and for helping promote the social imperative for tourism as a positive force in societies. This has been one of the main priorities for us when compiling this new handbook on social tourism.

Published eight years after the first edited book on social tourism (McCabe et al. 2012), this volume attempts to provide a more complete (though of course not exhaustive) insight into the progress of social tourism research in recent years, providing examples of recent and innovative research. As there is not yet enough research on employment and domestic tourism within the social tourism field, the book focuses mainly on the general development of social tourism, policies and beneficiaries and case studies integrating the supply side.

The book is structured in five parts, presenting a wide variety of topics that will enable readers to obtain a full understanding of the social tourism phenomenon.

Part I, 'Historical and socio-political context', provides the historical context for social tourism development. Chapter 2 by Louis Jolin investigates the evolution of social tourism in relation to the given socio-political context in three successive time periods, namely from 1936 to the early 1980s, from the 1980s to the end of the twentieth century and finally in the contemporary period of the new millennium. In Chapter 3, Claire Billen provides a brief social history of leisure and time use, starting from the pre-industrial age to explain that the desire to go on holiday, and the current practices of holiday-making, result from a long series of historical junctures.

Part II of the book, 'Social tourism in context', tackles current and topical conditions and perspectives of social tourism. In Chapter 4, Erica Schenkel and Marcelo Vilela de Almeida reveal the high degree of relevance of social tourism in the Latin American context, where access to tourism continues to be unequal and primarily enjoyed by a social minority. Highlighting the lack of direct evidence for the economic impacts of social tourism initiatives, in Chapter 5 Joana Lima and Celeste Eusébio examine the potential role of social tourism in the economic development of local communities. In Chapter 6, Scott McCabe and Anya Diekmann discuss these issues by considering the position of tourism as a social right and in the context of 
research on social tourism and pose the question of how to ensure that opportunities to participate in tourism exist for everyone in society. In the following Chapter 7, participation in Spanish thermalism programmes is explored through the sustainability lens: José David Cisneros-Martínez and Antonio Fernández-Morales analyse Imserso trips from a social and economic point of view. Finally, Lynn Minnaert in Chapter 8 analyses the stakeholders' perspective in social tourism innovation through a large-scale listening project.

In Part III, 'Benefits and challenges', the authors tackle the benefits and challenges of social tourism in relation to well-being and the role social tourism can play for various groups. The various chapters depict facets that have only recently attracted the attention of tourism scholars. In Chapter 9, Philippa Hunter-Jones, Steve Flatt, Liz Crolley and Katie Neary examine the poorly researched relationship between social tourism and mental health and consider the implications for social tourism policy. In the light of funding cuts in thermal 'cure' treatments all over Europe, in Chapter 10 Anya Diekmann, Melanie Kay Smith and Jean-Paul Ceron examine how transformations from welfare to wellness policies are taking place across a number of countries in both Western and Eastern Europe, highlighting many of the main challenges confronting the thermal destinations. Chapter 11, by Gareth Shaw, Scott McCabe and Julie Wooler, assesses the role of the voluntary sector in social tourism through an analysis of recent research undertaken with charities, tourism industry representatives and social services professionals working either directly or indirectly in the supply of social tourism in the UK. Chapter 12, by Yael Ram, then looks at nature as a source of various tangible and intangible benefits for people and the challenges of providing access to all groups of society. In Chapter 13, Martin Vincent discusses the relationship between ageing and social tourism due to changes of health- and socio-economic conditions through an analysis of social tourism policies at European and national levels.

Part IV of the book, 'Beneficiaries: implementation of social tourism', investigates the implementation of social tourism policies for the different target groups, starting in Chapter 14 with the elderly: Nigel Morgan, Lintje Siehoyono Sie and Jocelyn Finniear discuss the opportunities such holidays provide participants for escape, reminiscence, respite, companionship and reflection and the challenges they simultaneously present related to anxiety. Victoria Eichhorn examines the different dimensions of social exclusion with a particular focus on people with a disability in Chapter 15. In terms of overcoming intrapersonal deficiencies, the user base for social tourism should be widened to incorporate everyone with access needs. Drawing upon psychology studies on unemployment, social tourism research, and unemployment policy literature, Konstantinos Kakoudakis in Chapter 16 explicates the linkages between the benefits of social tourism participation for economically and socially disadvantaged groups, including unemployed individuals, and the aims of labour market policies in general, and 'active' policies in particular. In Chapter 17, Tahira Kosar investigates how social tourism can act as a catalyst to develop and enhance self-efficacy in disadvantaged families. In Chapter 18, Elke Hermans, Elien Herregodts and Veerle Cops present the outcomes of a study looking into 
intergenerational travellers and whether a specific offer by travel organizations for this type of holiday is an added value and what are the key reasons for choosing an intergenerational holiday.

Part V of the book, 'National case studies', presents case studies from various countries beginning with an example from France. Ana Cecilia Reyes Uribe examines in Chapter 19 a social tourism lodging enterprise highlighting managerial practices based on a social economy model, promoting social justice, job and wealth generation, family and community cohesion, non-discrimination policies, and pride and identity of cultural and natural French heritage. Elli Vento and Raija Komppula present in Chapter 20 a case study of the practices and implementation of social tourism in Finland. The main focus is on the evolution of the Finnish social tourism system, as well as the main target groups and practices of Finnish social tourism. In Chapter 21, Neil Carr and Heike Schänzel examine the historic and current state of social tourism in New Zealand and the potential future need for it due to a wide array of social intolerances, discriminatory practices, and inequalities challenging New Zealand's society. In Chapter 22, Joanne Pyke and Sarah Pyke present a case study where they analyse the impact of a one-day excursion on the subjective well-being of a group of Aboriginal people in Canada. Social tourism in China is examined by Guanghui Qiao and Bruce Prideaux in Chapter 23. The authors discuss a range of issues related to the development of social tourism in China including governmental policy and provide several case studies that demonstrate approaches that have been adopted to implement social tourism strategies. In the final Chapter 24, Adriana E. Estrada-González discusses social tourism in Mexico by reviewing its background, highlighting the need to conduct research on senior citizens, and providing evidence of seniors' experience when travelling with a planned social tourism programme.

\section{CONCLUSIONS}

Social tourism concerns the inclusion of all members of a society in participation in tourism (Haulot 1981). Such participation is made possible through the provision of some form of system of social or welfare support. Whilst it is tempting from our point of view to raise the concept of social tourism to be something of a panacea to the challenges identified in this introduction, this is far from our aim and the reality. Social tourism is a very small piece of the complex puzzle that makes up the global tourism industry. And yet, it is a progressive and socially motivated type of activity, often involving multiple stakeholders across the tourism sector and a range of other agencies. Not only does this mean that social tourism is more likely to have a broader view on the needs and demands as well as the types of necessary experiences and provisions required, it is more likely to involve better planning and management. This means that social tourism could offer a broader model for general tourism policy and management in the future.

The tourism industry is often accused of being fragmented, unable to share resources, integrate systems and coordinate actions. Due to scarcity of resources, an 
inability for any one agency or stakeholder to control or own all necessary information, and a strong social desire to cooperate, social tourism operators and agencies do not suffer from the pressures of a neoliberalist focus on competition and profit, which potentially provides a template for future integration of the tourism industry in activities and programmes that could respond or react to the global challenges outlined above.

Given that these grand challenges facing the tourism industry pose threats to the very existence of the tourism we have come to recognize and value, it is worth reminding ourselves of the broader imperative for tourism as outlined in the UNWTO Manila Declaration on World Tourism in 1980, which specifically recognized the links between the rights of workers to paid holidays and the development of modern mass tourism participation. Tourism is essential to the life of nations, and particularly important as a route to development, fostering peace and international understanding, which have never been more important than at the current uncertain times. Social tourism also has a role to play in these lofty social ideals and can contribute to economic and sustainable development in destinations.

We hope that the book can make a small, but definite contribution by giving more of a voice to social tourism research and its potential role in addressing the challenges of tourism development, and overall, that you enjoy reading it.

\section{REFERENCES}

Ballas, D., Dorling, D., and Hennig, B. (2017). Analysing the regional geography of poverty, austerity and inequality in Europe: A human cartographic perspective. Regional Studies, 51(1), 174-185.

Baum, T. (2015). Human resources in tourism: Still waiting for change? A 2015 reprise. Tourism Management, 50, 204-212.

Becken, S. (2019). Decarbonising tourism: Mission impossible? Tourism Recreation Research, 44(4), 419-433.

Buhalis, D., and Darcy, S. (Eds.). (2010). Accessible tourism: Concepts and issues. Bristol: Channel View Publications.

Butcher, J. (2003). The moralisation of tourism: Sun, sand ... and saving the world? (Contemporary Geographies of Leisure, Tourism and Mobility). London: Routledge.

Cisneros-Martínez, J. D., McCabe, S., and Fernández-Morales, A. (2018). The contribution of social tourism to sustainable tourism: A case study of seasonally adjusted programmes in Spain. Journal of Sustainable Tourism, 26(1), 85-107.

Diekmann, A., and McCabe, S. (2011). Systems of social tourism in the European Union: A critical review. Current Issues in Tourism, 14(5), 417-430.

Diekmann, A., McCabe, S., and Cardoso Ferreira, C. (2018). Social tourism: Research advances, but stasis in policy - bridging the divide. Journal of Policy Research in Tourism, Leisure and Events, 10(3), 181-188.

Diekmann, A., McCabe, S., and Minnaert, L. (2012). Social tourism today: Stakeholders, and supply and demand factors. In S. McCabe, L. Minnaert, and A. Diekmann (Eds.), Social tourism in Europe: Theory and practice (pp. 35-47). Bristol: Channel View Publications.

European Economic and Social Committee (2006). Opinion of the Economic and Social Committee on Social Tourism in Europe. Brussels: EESC. 
Eurostat (2019). https://ec.europa.eu/eurostat/statistics-explained/index.php?title=Population _structure_and_ageing (accessed October 2019).

Eusébio, C., Carneiro, M. J., Kastenholz, E., and Alvelos, H. (2013). The economic impact of health tourism programmes. In A. Matias, P. Nijkamp, and M. Sarmento (Eds.), Quantitative methods in tourism economics (pp. 153-174). Heidelberg: Physica.

Eusébio, C., Carneiro, M. J., Kastenholz, E., and Alvelos, H. (2016). The impact of social tourism for seniors on the economic development of tourism destinations. European Journal of Tourism Research, 12, 5-24.

Guzman-Castillo, M., Ahmadi-Abhari, S., Bandosz, P., Capewell, S., Steptoe, A., Singh-Manoux, A., Kivimaki, M., Shipley, M. J., Brunner, E. J., and O'Flaherty, M. (2017). Forecasted trends in disability and life expectancy in England and Wales up to 2025: A modelling study. The Lancet Public Health, 2(7), e307-e313.

Hall, D., and Brown, F. (2006). Tourism and welfare: Ethics, responsibility and sustained well-being. Wallingford: CABI.

Haulot, A. (1981). Social tourism: Current dimensions and future developments. International Journal of Tourism Management, 2(3), 207-212.

Heidenreich, M. (Ed.). (2016). Exploring inequality in Europe: Diverging income and employment opportunities in the crisis. Cheltenham, UK and Northampton, MA, USA: Edward Elgar Publishing.

Higgins-Desbiolles, F. (2006). More than an "industry": The forgotten power of tourism as a social force. Tourism Management, 27(6), 1192-1208.

Lenzen, M., Sun, Y., Faturay, F., Ting, Y., Geschke, A., and Malik, A. (2018). The carbon footprint of global tourism. Nature Climate Change, 8, 522-528.

McCabe, S. (2009). Who needs a holiday? Evaluating social tourism. Annals of Tourism Research, 36(4), 667-688.

McCabe, S. (2018). Social tourism and its contribution to sustainable tourism. Cuadernos Económicos de Información Comercial Española, 93, 29-44.

McCabe, S. (2019). "Tourism for all?" Considering social tourism: A perspective paper. Tourism Review, 75(1), 61-64.

McCabe, S., and Johnson, S. (2013). The happiness factor in tourism: Subjective well-being and social tourism. Annals of Tourism Research, 41, 42-65.

McCabe, S., Minnaert, L., and Diekmann, A. (Eds.). (2012). Social tourism in Europe: Theory and practice. Bristol: Channel View Publications.

McCall, L., and Percheski, C. (2010). Income inequality: New trends and research directions. Annual Review of Sociology, 36, 329-347.

Mélon, M., Agrigoroaei, S., Diekmann, A., and Luminet, O. (2018). The holiday-related predictors of wellbeing in seniors. Journal of Policy Research in Tourism, Leisure and Events, 10(3), 221-240.

Minnaert, L. (2012). Social tourism as opportunity for unplanned learning and behavior change. Journal of Travel Research, 51(5), 607-616.

Minnaert, L., Diekmann, A., and McCabe, S. (2012). Defining social tourism and its historical context. In S. McCabe, L. Minnaert, and A. Diekmann (Eds.), Social tourism in Europe: Theory and practice (pp. 18-30). Bristol: Channel View Publications.

Minnaert, L., Maitland, R., and Miller, G. (2009). Tourism and social policy: The value of social tourism. Annals of Tourism Research, 36(2), 316-334.

Morgan, N., Pritchard, A., and Sedgley, D. (2015). Social tourism and well-being in later life. Annals of Tourism Research, 52(1), 1-15.

Partington, R. (2018). How unequal is Britain and are the poor getting poorer? The Guardian, 5 September. https://www.theguardian.com/inequality/2018/sep/05/qa-how-unequal-is -britain-and-are-the-poor-getting-poorer (accessed 9 January 2020).

Scheyvens, R., and Biddulph, R. (2018). Inclusive tourism development. Tourism Geographies, 20(4), 589-609. 
Schnitzler, M. (2019). Handicap, vieillissement et vieillesse. Revue de la littérature à partir de la France. Gerontologie et société, 41(2), 45-60.

Shaw, G., Veitch, C., and Coles, T. I. M. (2005). Access, disability, and tourism: Changing responses in the United Kingdom. Tourism Review International, 8(3), 167-176.

Smith, M. K., and Diekmann, A. (2017). Tourism and wellbeing. Annals of Tourism Research, $66,1-13$.

UNWTO (2019). International Tourism Highlights, 2019 Edition. Madrid: UN World Tourism Organization.

Visit England (2018). Visitor Attraction Trends in England 2018 - Full Report. https://www .visitbritain.org/sites/default/files/vb-corporate/Documents-Library/documents/England -documents/annual_attractions_survey_2018_trends_report.pdf (accessed 20 January 2020).

Walton, J. K. (2013). "Social tourism" in Britain: History and prospects. Journal of Policy Research in Tourism, Leisure and Events, 5(1), 46-61.

Yu, H. W., Chiang, T. L., Chen, D. R., Tu, Y. K., and Chen, Y. M. (2018). Trajectories of leisure activity and disability in older adults over 11 years in Taiwan. Journal of Applied Gerontology, 37(6), 706-727. 